\title{
The Importance of Outcome Measures in the Management of Inflammatory Rheumatic Diseases
}

\author{
Juan Molina Collada $\mathbb{D}^{1,2}$ \\ Laura Trives' \\ Isabel Castrejón (D) ${ }^{1,2}$ \\ 'Department of Rheumatology, Hospital \\ General Universitario Gregorio Marañón, \\ Madrid, Spain; ${ }^{2}$ Instituto de Investigación \\ Sanitaria Gregorio Marañón (liSGM), \\ Madrid, Spain
}

Correspondence: Isabel Castrejón Department of Rheumatology, Hospital General Universitario Gregorio Marañón, Doctor, Esquerdo, 46, 28007, Madrid, Spain

Tel +349l426921I

Email isabel.castrejon@salud.madrid.org

\begin{abstract}
Rheumatic inflammatory diseases include a diverse and heterogeneous group of multifaceted disorders in which clinical history and physical examination are essential to make treatment choices and for optimizing outcomes. Composite outcome measures have become very relevant in rheumatology to evaluate disease activity as they capture the most important dimensions of the disease into one single measure. Most outcome measures may include disease manifestations, laboratory data, physician examination as well as the patient perspective as different outcome dimensions of the disease into a simple index. These outcome measures have proved their utility for guiding treatment in treat-to- target strategies and personalized medicine, with remission being the ultimate goal. In this narrative review, we go over the most commonly used outcome measures in rheumatoid arthritis, spondyloarthropathies, including psoriatic arthritis, and systemic lupus erythematosus to provide a practical summary for clinicians for everyday routine care.
\end{abstract}

Keywords: outcome measures, disease activity, remission, physician management, rheumatoid arthritis, systemic lupus erythematosus, spondyloarthropathies, psoriatic arthritis

\section{Introduction}

The clinical approach in rheumatology is different from the approach in other chronic diseases in several important aspects. The two most important ones are: (1) the most relevant information in diagnosis and management decisions come from a patient history and physical examination, ${ }^{1}$ and (2) there is no single "gold standard" biomarker to evaluate disease activity in all individual patients, thus clinical evaluation is based on a combination of physician's judgment and patient's clinical picture, supported by laboratory and imaging findings. Multiple instruments applied in rheumatology aim to capture all these aspects to assess disease activity and other critical domains. Disease activity refers to clinical or laboratory abnormalities that can be attributed to the disease and are likely to be reversible with therapy. Outcome measures in rheumatology can be generic or disease-specific, and are important to evaluate clinical status, treatment response, and to guide clinical decisions.

Although rheumatologists generally apply the term "objective" to laboratory tests, ancillary studies or physician evaluation, and information from a patient's history are especially relevant in rheumatology. Patients' symptoms can be transformed from a narrative description into quantitative data using standardized, structured, and validated patient self-reported outcome measures (PROMs). PROMs not only are relevant to incorporate the patient's perspective, they have 
also become central to measure treatment response in clinical trials and routine care in rheumatology. ${ }^{2}$

In this narrative review we aim to summarize the most frequently used outcome measures to evaluate disease activity in rheumatoid arthritis (RA), spondyloarthropathies (SpA) including psoriatic arthritis (PsA), and systemic lupus erythematosus (SLE) to provide a practical approach for clinicians.

\section{Outcome Measures in Rheumatoid Arthritis}

Rheumatoid factor (RF) was discovered in the $1940 \mathrm{~s}^{3}$ and it was then anticipated that laboratory tests could serve as "gold standard" biomarkers to diagnose and manage patients with RA. More recently anticyclic citrullinated peptide antibody (ACPA) has been of great importance in understanding pathogenesis and developing new therapies. However, both biomarkers have some limitations for clinical diagnosis and disease activity assessment. Although ACPA seems more specific and has been described as a better predictor of erosive disease, ${ }^{4}$ only around $60 \%$ and $73 \%$ of patients with RA present RF or ACPA positive, respectively, at the first visit.

Acute phase reactants including erythrocyte sedimentation rate (ESR) and C-reactive protein (CRP) are useful biomarkers to assess disease activity and are frequently used in clinical trials and routine care. Both serologic abnormality and elevated acute-phase response are included in the new classification criteria for RA, ${ }^{5}$ nevertheless they can be within normal range in a considerable proportion of patients. ${ }^{6}$

Because of these limitations in laboratory biomarkers, disease activity is generally assessed in rheumatology using combinations of single measures into an overall single score or pooled index. The use of pooled indices has several advantages: (1) simplifies clinical assessment, providing reliable estimates of disease activity and severity, (2) allows comparison of multiple data points between visits and groups of patients, (3) pooled indices show higher sensitivity to change than single items, ${ }^{7}$ (4) both the American College of Rheumatology and the European League Against Rheumatism recommend their use. ${ }^{8,9}$ A summary of the most commonly used indices in RA with the most relevant aspects is presented in Table 1.

The disease activity measure (DAS) is the first composite index proposed for RA. It was developed from a large prospective study in which the initiation or changed treatment by the treating rheumatologist was the external standard for disease activity. ${ }^{10}$ A simplified DAS $28^{11}$ was subsequently developed, based on a 28 joint count for tender and swollen counts, ESR, and a patient global assessment on a visual analogue scale (0-100). DAS28 can be calculated using ESR or CRP, although these alternative versions do not provide equivalent results, ${ }^{12}$ and require different cut-off for disease activity categories. ${ }^{13}$ Both DAS and DAS2 8 are based on complex formulas and scoring is available at a website (www.das-score.nl).

To overcome the formula complexity, Smolen et al. developed the Simplified Disease Activity Index (SDAI) as a derivation of the DAS28, adding a physician global assessment. ${ }^{14} \mathrm{~A}$ version not including any acute-phase reactant, the Clinical Disease Activity Index (CDAI), has also beendeveloped. ${ }^{15}$ It seems that the acute phase reactants can be interpreted independently and do not contribute to pooled indices enough to change results on disease activity. ${ }^{16}$ Different categories for disease activity have been defined for both CDAI and SDAI (Table 1).

Furthermore, a composite index only including outcomes from the patient's perspective or PROMs has been developed. RAPID3 is a pooled index including the three RA Core Data Set: physical function, pain, and patient global assessment. Although it only includes patient measures, RAPID3 have shown good correlation with DAS28 and CDAI and to distinguish treatment from placebo in clinical trials. ${ }^{17}$ RAPID3 is useful to detect improvement ${ }^{18}$ and more feasible to implement a treat-to-target strategy in routine care. ${ }^{19}$ A RAPID3 minimally clinical relevance of 3.8 over 30 units has been proposed for patients with RA. $^{20}$

The use of pooled indices to guide a treat-to-target strategy yields better long-term outcomes than a conventional approach to therapy. Remission can be defined for each composite index, specific cut-offs are presented in Table 1, to serve as the target for treatment, adjusting by patients' characteristics as comorbidity, damage and patient's preferences. A more stringent definition for remission was proposed by the American College of Rheumatology and the European League Against Rheumatism together with the Outcome Measures in Rheumatology Initiative (OMERACT), the Boolean criteria (tender and swollen joint counts, CRP and patient global assessment; all these individual items are required to be lower or equal to 1$).{ }^{21} \mathrm{In}$ routine care, acute-phase response measures may be not available at every visit, therefore the members of the 
Table I Composite Indices to Assess Disease Activity in Patients with RA

\begin{tabular}{|c|c|c|c|c|c|c|}
\hline Indices & Items & $\begin{array}{l}\text { Categories } \\
\text { Remission } \\
\text { Low/Mod/ } \\
\text { High }\end{array}$ & Feasibility & $\begin{array}{c}\text { Reliability (Cronbach's } \alpha \text {, } \\
\text { Intraclass Correlation } \\
\text { Coefficient) }\end{array}$ & $\begin{array}{l}\text { Criterion Validity } \\
\text { (Gold Standard) }\end{array}$ & Responsiveness \\
\hline $\begin{array}{l}\text { DAS28 } \\
(0-9.4) \\
\text { Prevoo } \\
1995^{11}\end{array}$ & $\begin{array}{l}28 \text { SJC/ } \\
\text { TJC } \\
\text { PATGL } \\
\text { ESR/ } \\
\text { CRP }\end{array}$ & $\begin{array}{l}\text { Remission } \\
<2.6 \\
2.6 / 3.2 / 5.1 \\
\text { Significant } \\
\text { change = } \\
1.2^{56}\end{array}$ & $\begin{array}{l}\text { 5-8 min } \\
\text { Includes laboratory } \\
\text { data Complex } \\
\text { formula }\end{array}$ & $\begin{array}{l}\alpha=0.654 \\
\text { I week apart } \\
\text { ICC }=0.85\end{array}$ & $\begin{array}{l}\text { EULAR response } \\
\text { kappa }=0.80-0.82 \\
\text { CDAI Kappa }=0.70\end{array}$ & $\begin{array}{l}\text { SRM }=1.58 \text { slightly } \\
\text { higher than DAS }\end{array}$ \\
\hline $\begin{array}{l}\text { SDAI } \\
(\mathbf{0 - 8 6 )} \\
\text { Smolen } \\
2003^{14}\end{array}$ & $\begin{array}{l}28 \mathrm{SJCl} \\
\text { TJC } \\
\text { PATGL } \\
\text { DOCGL } \\
\text { CRP }\end{array}$ & $\begin{array}{l}\text { Remission } \\
<3.3 \\
3.3 / 11 / 26 \\
\text { Significant } \\
\text { change }=16\end{array}$ & $\begin{array}{l}2-3 \mathrm{~min} \\
\text { Includes laboratory } \\
\text { data }\end{array}$ & $\begin{array}{l}\alpha=0.783 \\
\text { I week apart } \\
\text { ICC }=0.88\end{array}$ & $\begin{array}{l}\text { SDAI/DAS28 } \\
r=0.80\end{array}$ & $\begin{array}{l}\text { Change in SDAI/ } \\
\text { HAQ linear } \\
\text { relationship } \\
r=0.56-0.57\end{array}$ \\
\hline $\begin{array}{l}\text { CDAI } \\
(\mathbf{0 - 7 6 )} \\
\text { Aletaha } \\
2005^{15}\end{array}$ & $\begin{array}{l}28 \mathrm{SJCl} \\
\text { TJC } \\
\text { PATGL } \\
\text { DOCGL }\end{array}$ & $\begin{array}{l}\text { Remission } \\
<2.8 \\
2.8 / 10 / 22\end{array}$ & $\begin{array}{l}<2 \text { min } \\
\text { Does NOT include } \\
\text { laboratory data }\end{array}$ & $\begin{array}{l}\alpha=0.783 \\
\text { I week apart } \\
\text { ICC }=0.89\end{array}$ & $\begin{array}{l}\text { CDAI/DAS28 } \\
\text { Kappa }=0.70 \\
r=0.89\end{array}$ & $\begin{array}{l}\text { Change in CDAI/ } \\
\text { HAQ linear } \\
\text { relationship } \\
r=0.47-0.56\end{array}$ \\
\hline $\begin{array}{l}\text { RAPID3 } \\
(\mathbf{0}-\mathbf{3 0}) \\
\text { Pincus } \\
2008^{57}\end{array}$ & $\begin{array}{l}\text { MHAQ } \\
\text { Pain } \\
\text { VAS } \\
\text { PATGL }\end{array}$ & $\begin{array}{l}\text { Remission } \\
<3 \\
3 / 6 / 12 \\
M C I I=3.8 \\
\text { units }^{20}\end{array}$ & $\begin{array}{l}<2 \mathrm{~min} \\
\text { Does NOT include } \\
\text { laboratory data }\end{array}$ & $\alpha=0.820$ & $\begin{array}{l}\text { DAS28 rho }=0.36- \\
0.6 \mathrm{I}, \mathrm{CDAl} \text { rho }= \\
0.54-0.77\end{array}$ & - \\
\hline
\end{tabular}

Abbreviations: DAS, disease activity score; CDAI, Clinical Disease Activity Index; SJC, swollen joint counts; TJC, tender joint counts; PATGL, patient global assessment, DOCGL, physician global assessment; CRP, C-reactive protein; ESR, erythrocyte sedimentation rate; MHAQ, Modified Health Assessment Questionnaire; ICC, Intraclass Correlation Coefficient; SRM, standardized response mean; MCII, Minimal Clinically Important Improvement; VAS, visual analogue scale.

American College of Rheumatology/European League Against Rheumatism committee proposed an alternative definition for remission excluding acute phase reactants.

RAPID3 remission definition (cut-off $<3$ ) is less stringent in comparison with the Boolean definition. However, when adding a careful joint examination with $\leq 1$ swollen joint, the kappa agreement for Boolean/CDAI and Boolean/ RAPID3 was similar, ${ }^{22}$ providing a more stringent definition easily applicable in routine care. For any of the proposed remission criteria, older patients with high scores for pain have been shown to be less likely to be in remission. ${ }^{23}$

In summary, RA is a very heterogeneous and complex disease, which requires a combination of multiple outcomes to evaluate disease activity. Each of these composite indices frequently used in patients with RA exhibit different advantages and limitations. All of them may be affected by chronic damage and comorbid illnesses such as secondary fibromyalgia, resulting in potential inappropriate use of costly therapy. On the other hand, a lack of recognition of sub-clinical disease may result in joint damage, highlighting the importance of the ability of the clinician to consider all the important clinical information when evaluating patients with RA.

\section{Outcome Measures in Spondyloarthritis and Psoriatic Arthritis}

The term spondyloarthritis include a group of heterogeneous diseases with chronic inflammation of the axial skeleton and pelvis, peripheral arthritis, enthesitis, dactylitis, and other extra-articular features such as uveitis, psoriasis, and inflammatory bowel disease. There is mounting evidence that early effective treatment of inflammation can change disease outcome. The major challenge is to assess disease activity and to adjust treatment accordingly. To this regard, pooled indices are more likely to give complete and reliable information about the level of disease activity. ${ }^{24}$ Disease activity measures in spondyloarthritis, are summarized here and presented in Table 2 . 
Table 2 Composite Indices to Assess Disease Activity in Patients with Spondylopathies

\begin{tabular}{|c|c|c|c|c|c|c|}
\hline Indices & Items & $\begin{array}{l}\text { Categories } \\
\text { Remission } \\
\text { Low/Mod/ } \\
\text { High }\end{array}$ & Feasibility & $\begin{array}{l}\text { Reliability } \\
\text { (Cronbach's } \alpha \text {, } \\
\text { Intraclass } \\
\text { Correlation } \\
\text { Coefficient) }\end{array}$ & $\begin{array}{l}\text { Criterion } \\
\text { Validity } \\
\text { (Gold } \\
\text { Standard) }\end{array}$ & Responsiveness \\
\hline $\begin{array}{l}\text { BASDAI } \\
(\mathbf{0}-10) \\
\text { Garrett } \\
1994^{26}\end{array}$ & $\begin{array}{l}0-10 \text { VAS fatigue, total } \\
\text { back pain, peripheral } \\
\text { joints pain, enthesitis, } \\
\text { and MS }\end{array}$ & $\begin{array}{l}\text { Inactive } \\
<2.5 \\
\text { High DA = 4 } \\
\text { Highly } \\
\text { active }>6.9 \\
\text { DA flares }\end{array}$ & $\begin{array}{l}30 \mathrm{~s}-2 \mathrm{~min} \\
\text { Do NOT } \\
\text { includes } \\
\text { laboratory } \\
\text { data }\end{array}$ & $\begin{array}{l}\alpha=0.84-0.87 \\
\mathrm{ICC}=0.94\end{array}$ & Not Tested & $\begin{array}{l}\text { SRM }=-0.74 \text { for improvement and } \\
0.60 \text { for deterioration in health }\end{array}$ \\
\hline $\begin{array}{l}\text { ASDAS } \\
\text { (0-7) } \\
\text { Lukas } \\
2009^{33}\end{array}$ & $\begin{array}{l}\text { CRP/ESR, back pain, } \\
\text { duration of MS, } \\
\text { peripheral pain /swelling } \\
\text { \& PATGL }\end{array}$ & $\begin{array}{l}\text { Inactive } \\
<1.3 \text { Low } \\
\text { DA }<2.1 \\
\text { High }<3.5 \\
\text { Very high } \\
>3.5\end{array}$ & $\begin{array}{l}>1 \text { minute } \\
\text { Complex } \\
\text { scoring } \\
\text { Includes } \\
\text { laboratory } \\
\text { data }\end{array}$ & Not Tested & $\begin{array}{l}\text { PATGL } r= \\
0.74\end{array}$ & $\begin{array}{l}\text { Guyatt's ES }=2.4 \text { (ASDAS-CRP), } \\
2.2 \text { (ASDAS-ESR) versus BASDAI- } \\
\text { ES }=1.5\end{array}$ \\
\hline $\begin{array}{l}\text { DAPSA } \\
\text { (0-204) } \\
\text { Schoels } \\
2010^{38}\end{array}$ & $\begin{array}{l}\text { PATGL } \\
\text { VAS pain } \\
68 \text { TJC } \\
66 \text { SJC } \\
\text { CRP }\end{array}$ & $\begin{array}{l}\text { Remission } \\
\leq 4 \text { Low DA } \\
\leq 14 \\
\text { Moderate } \\
\text { DA >14 } \\
\text { High DA } \\
>28\end{array}$ & $\begin{array}{l}<5 \text { minutes } \\
\text { Includes } \\
\text { laboratory } \\
\text { data }\end{array}$ & Not Tested & $\begin{array}{l}\text { DAS28 } r= \\
0.78 \\
\text { SDAI } r= \\
0.95\end{array}$ & $\begin{array}{l}\text { Good sensitivity to change } \\
\text { High discriminant capability: Effect } \\
\text { sizes high }(>0.8) \text { for the active } \\
\text { treatment arm in a retrospective } \\
\text { analysis }\end{array}$ \\
\hline $\begin{array}{l}\text { CPDAI } \\
(0-15) \\
\text { Mumtaz } \\
2011^{39}\end{array}$ & $\begin{array}{l}66 \mathrm{SJC} / 68 \mathrm{TJC} \\
\text { HAQ } \\
\text { PASI and DLQI } \\
\text { dactylitis, enthesitis } \\
\text { Spinal manifestations }\end{array}$ & $\begin{array}{l}\text { Remission } \\
<2 \\
\text { Low DA <4 } \\
\text { Moderate } \\
\text { DA }<7 \\
\text { High DA }>7\end{array}$ & $\begin{array}{l}8 \text { minutes } \\
\text { Does NOT } \\
\text { include } \\
\text { laboratory } \\
\text { data }\end{array}$ & Not tested & $\begin{array}{l}\text { HAQ rho } \\
=0.76 \\
\text { PATGL } r= \\
0.834 \\
\text { DOCGL } \\
r=0.825\end{array}$ & $S R M=0.60$ \\
\hline
\end{tabular}

Abbreviations: BASDAI, Bath Ankylosing Spondylitis Disease Activity Index; ASDAS, Ankylosing Spondylitis Disease Activity Score; CPDAI, Composite Psoriatic Disease Activity Index; DAPSA, Disease Activity for Psoriatic Arthritis; SJC, swollen joint counts; TJC, tender joint counts; PATGL, patient's global assessment, DOCGL, physician global assessment; CRP, C-reactive protein; ESR, erythrocyte sedimentation rate; MS, morning stiffness; MHAQ, Modified Health Assessment Questionnaire; ICC, Intraclass Correlation Coefficient; SRM, standardized response mean; ES, effect size; MCII, Minimal Clinically Important Improvement; VAS, visual analogue scale.

\section{Axial Spondyloarthritis}

Axial spondyloarthritis is characterized by inflammatory back pain, bony fusion of the spine, decreased mobility, functional impairment and decreased quality of life. Currently used single components have limitations because they measure only one aspect of the disease. The Assessment of Spondyloarthritis International Society (ASAS) has proposed the following domains to be included in the disease activity evaluation, ${ }^{25}$ spinal pain, a patient global assessment, a 44 joint count, enthesitis, duration of morning stiffness, and the level of fatigue. All these domains were initially proposed for ankylosing spondylitis (AS) but can be applied to both radiographic and non-radiographic axial SpA.
The Bath Ankylosing Spondylitis Disease Activity Index (BASDAI $)^{26}$ is the most widely used disease activity composite score in axial $\mathrm{SpA}$. It is a self-reported questionnaire including five individual questions scored on a $0-10$ visual analogue scale, to evaluate fatigue, total back pain, peripheral joints pain, enthesitis, and severity of morning stiffness; an additional question evaluates duration of morning stiffness with 10 representing a duration of 2 hours or longer. ${ }^{26}$ To calculate the total BASDAI, the average of severity and duration of morning stiffness is calculated, added to the other 4 items, and divided by 5 to give a final BASDAI score of $0-10$. A cut-off point of 4 has been used in trials with TNF blockers as the threshold for "high disease activity", ${ }^{27-29}$ which is similar to the 
BASDAI cut-off point of 3.9 based on patients' perceptions of symptom relief. ${ }^{29}$ Additional cut-off points for "inactive" $<2.5$ versus "highly active" $>6.9$ for disease activity flares have been described. ${ }^{30}$ BASDAI may not reflect entirely the inflammatory processes and does not consider the potential redundancy of individual items. A modified version of the BASDAI (mini-BASDAI) has been developed excluding peripheral manifestations, with no better correlation with other markers of disease versus the original BASDAI. ${ }^{31}$

Although disease activity is commonly assessed using BASDAI, which is a fully patient self-reported questionnaire, it has been previously described to reflect a discordance between patients and physician's disease's perception. $^{32}$ Patients rate mainly symptoms and complaints as relevant to define disease activity in contrast with physicians rating variables reflecting inflammation and severity, including their disease evaluation and acute phase reactants as surrogates of inflammation. As consequence, the ASAS group developed in 2009 a new composite measure for disease activity in axial SpA: the Ankylosing Spondylitis Disease Activity Score (ASDAS). ASDAS includes some items from BASDAI such as back pain, peripheral joint pain, and duration of morning stiffness in addition to an acute phase reactant, either ESR or CRP. ${ }^{33}$ The ASDAS is a well-balanced index between the patient's and physician's perspective, covering the underlying construct of disease activity and designed to avoid redundancy. The ASDAS discriminative ability has been explored in multiple cohorts, and these studies have shown a better performance of the ASDAS versus the BASDAI, and also better versus the single-item variables included in the BASDAI, patient and physician global assessments, and acute phase reactants alone. ${ }^{34}$ ASDAS also performs well in peripheral and early forms of $\mathrm{SpA}$, being a promising tool to measure disease activity in patients with peripheral and early stages of $\mathrm{SpA}^{35}$ However, it requires availability of acute phase reactants, not always accessible at the time of the visit. As it also requires a complex formula to be calculated, ASDAS may be difficult to incorporate in routine care.

Remission or low disease activity has become an attainable treatment goal in axial SpA. No universally accepted definition for remission is available, however several definitions based on different tools have been proposed. In 2001, the ASAS proposed a preliminary definition of partial remission as a value no greater than 2 on a 0 -10 visual analogue scale for four different items: patient global assessment, spinal pain, physical function (per BASFI), and inflammation (as the sum of the scores on BASDAI items 5 and 6). ${ }^{36}$ In addition, an ASDASCRP cut-off value of 1.3 has been proposed to define inactive disease. It is important to highlight that inactive disease is not synonymous with remission; the later encompasses additional disease dimensions such as extraarticular manifestations (e.g., psoriasis, uveitis, and inflammatory bowel disease), comorbidities, and patient's perceptions. In addition, imaging data, duration and stability of remission after discontinuation of therapy need to also be incorporated in the remission concept. ${ }^{37}$

\section{Psoriatic Arthritis}

Psoriatic arthritis (PsA) is a very heterogeneous disease characterized by skin involvement in addition to peripheral and/or axial joints arthritis, nails involvement, and enthesitis. All these different domains may significantly vary and change over time with an important impact on patients' quality of life. In the majority of patients with PsA, disease manifests in the skin and nails before onset of inflammatory arthritis. Consequently, dermatology or general practice clinicians are in an excellent position to screen for the first signs of PsA to refer patients for a rheumatology evaluation.

Because of the heterogeneity of symptoms in PsA, composite measures of disease activity seem more appropriate than assessment of individual domains. However, pooled indices to evaluate disease activity in PsA are not firmly established, and most of those currently in use have been derived from the ones for RA. RA pooled indices are based on 28 joint counts; therefore, they do not capture joints frequently affected in patients with PsA, highlighting the need for disease-specific instruments for PsA.

The first disease-specific instrument described in 2010, the Disease Activity Index for Psoriatic Arthritis (DAPSA), is calculated by the sum of the following items: (1) visual analogue scale pain and patient global assessment; (2) $66 \mathrm{SJCs}$ and $68 \mathrm{TJCs}$; and (3) CRP. ${ }^{38}$ DAPSA appears to be a valid instrument with high correlation with DAS28.

An additional pooled index, the Composite Psoriatic Disease Activity Index (CPDAI), ${ }^{39}$ includes the assessment of five domains: peripheral joints (SJC of 66 and TJC of 68), skin (using PASI), enthesitis, dactylitis and spinal manifestations (BASDAI and Ankylosing Spondylitis Quality of Life (ASQoL)), giving a CPDAI 
score range of 0 to 15 . The CPDAI has shown significant correlation with patient and physician global assessments, and discriminates well effectively treated patients in comparison with DAPSA. ${ }^{40}$

Similarly to the emerging paradigm of treat-to-target in RA, which requires a quantitative measurement of disease activity and numeric thresholds to define remission, a preliminary target for treatment haves been defined for patients with PsA. ${ }^{41}$ These criteria for Minimal Disease Activity have been developed by the GRAPPA group based on expert opinion about a set of hypothetical cases. $^{42}$ A patient with PsA is considered to be in Minimal Disease Activity when meeting 5 of the following 7 criteria: $\mathrm{TJC} \leq 1, \mathrm{SJC} \leq 1, \mathrm{PASI} \leq 3$, patient pain on a visual analogue scale $\leq 15$, patient global assessment on a visual analogue scale $\leq 20, \mathrm{HAQ} \leq 0.5$, and tender enthesis points $\leq 1$. The Minimal Disease Activity criteria, further validated in a cohort and a clinical trial, are now being implemented in prospective PsA clinical trials.

In summary, several outcome measures have been developed specifically to evaluate clinical disease activity in SpA and PsA. Most instruments have been validated and have strong evidence to support their use in clinical trials. However, validation is an ongoing process and these instruments should be further implemented in routine care as targeted simplified measures to guide a treat-to-target strategy. RAPID3, initially developed as a feasible instrument to be used in routine care in RA, show a similar sensitivity versus BASDAI and $\operatorname{ASDAS}^{43}$ and appears as valid as PASDAS and DAPSA in PsA. ${ }^{44}$

\section{Outcome Measures in Systemic Lupus Erythematosus}

To evaluate disease activity in systemic lupus erythematosus (SLE) is a challenge because of the extreme variability of the disease clinical picture due to the wide range of clinical and serological manifestations, with the coexistence of manifestations related to both inflammation and damage. Disease activity is a target of treatment in SLE and therefore it appears mandatory to objectively assess disease activity in SLE. The need to optimize the assessment of SLE has become evident in the context of observational studies and clinical trials.

The physician judgement of disease activity, generally considered as the "gold standard" for activity, has a great inter- as well as intra-rater variability highlighting the need for more comprehensive measures. Multiple activity measures have been developed, ${ }^{45,46}$ and can be classified in global score systems, which provide an overall measure of activity and individual organ/system assessment scales assessing activity in single organs. The main advantage of global scores is their relative "simplicity" to compare patients with different disease manifestations. Major limitations of these indices reside in the fact that the same score could be associated with different disease severity and improvement in one organ might be covered by worsening in another as the global score may remain unchanged. In contrast, individual organ/system indices capture the extreme variability of the disease itself. However, they have the limitation of being unable to give a stratification of patients with different organ involvement and are complex. Most commonly used indices are reviewed here and presented in Table 3.

The British Isles Lupus Assessment Group (BILAG) ${ }^{47}$ was developed based on the rheumatologist's intention to treat and includes the evaluation of disease activity in each individual organ system in the previous months. Activity in each organ system is scored from A for most active disease to $\mathrm{E}$ for no previous activity, with a combination of answers within each organ system allowing to obtain indications relative to a particular organ involvement.

The Systemic Lupus Erythematosus Disease Activity Index (SLEDAI) is a complex index first described in 1992 to assess disease activity. SLEDAI includes the evaluation of 24 variables in 9 organs or systems and laboratory parameters present in the last 10 days. According to SLEDAI, patients can be classified into remission (no disease activity) or low, moderate or severe activity. Its main limitation is its poor sensitivity to change. It was revised in 2002, the new version is the SLEDAI-2K which reflects ongoing disease activity and includes other manifestations such as scleritis and episcleritis. ${ }^{48}$ There is a high correlation between both versions.

Years later, the SELENA group developed a new version, the SELENA-SLEDAI Flare Index (SFI) based on SLEDAI items but including worsening of symptoms or appearance of new ones. It allows classifying patients in having mild/moderate flare or severe flares. Flares were defined by changes in the PGA or SLEDAI, and additional items not captured by a change in score of a disease activity measure and by treatment changes.

Disease activity and treatments used for it cause damage which is also important to be evaluated and measured because it also helps to predict mortality of patients. So, in 1996, the index called Systemic Lupus International 
Table 3 Composite Indices to Assess Disease Activity in Patients with SLE

\begin{tabular}{|c|c|c|c|c|c|c|}
\hline Indices & Items & $\begin{array}{c}\text { Categories } \\
\text { Remission } \\
\text { Low/Mod/High }\end{array}$ & Feasibility & $\begin{array}{c}\text { Reliability } \\
\text { (Cronbach's } \alpha, \\
\text { Intraclass } \\
\text { Correlation } \\
\text { Coefficient) }\end{array}$ & $\begin{array}{l}\text { Criterion } \\
\text { Validity } \\
\text { (Gold } \\
\text { Standard) }\end{array}$ & Responsiveness \\
\hline $\begin{array}{l}\text { BILAG } \\
2005 \\
\text { Isenberg } \\
2004^{47}\end{array}$ & $\begin{array}{l}\text { Individual organ } \\
\text { score including } \\
\text { manifestations in } 9 \\
\text { organ systems }\end{array}$ & $\begin{array}{l}A=\text { most active } \\
B=\text { intermediate } \\
C=\text { mild } \\
D=\text { inactive } \\
E=\text { no activity }\end{array}$ & $\begin{array}{l}\text { I5-30 minutes, } \\
\text { includes laboratory } \\
\text { data }\end{array}$ & $\begin{array}{l}\alpha=0.54-0.76 \\
I C C=0.509\end{array}$ & Not tested & $\begin{array}{l}\text { Coefficient of increase } \\
1.35 \text { and of decrease } 0.44\end{array}$ \\
\hline $\begin{array}{l}\text { SLEDAI- } \\
\mathbf{2 k} \\
\text { Gladman } \\
2002^{48}\end{array}$ & Global index & $\begin{array}{l}0=\text { no activity } \\
1-5=\text { mild } \\
6-10=\text { moderate } \\
11-19=\text { high } \\
\text { activity } \\
>20=\text { very high }\end{array}$ & $\begin{array}{l}10 \text { minutes } \\
\text { Includes } \\
\text { laboratory data }\end{array}$ & $\mathrm{ICC}=0.98$ & Not tested & $\begin{array}{l}\text { Highest association with } \\
\text { treatment between BILAG } \\
2004 \text { and SLEDAI-2K } \\
\text { (difference < < \%) }\end{array}$ \\
\hline $\begin{array}{l}\text { SLAQ } \\
\text { Karlson } \\
2003^{50}\end{array}$ & $\begin{array}{l}\text { Self-reported } \\
\text { questionnaire }\end{array}$ & $\begin{array}{l}\text { Response } \\
\text { categories: "no } \\
\text { problem", "mild", } \\
\text { "moderate" and } \\
\text { "severe" }\end{array}$ & $\begin{array}{l}10 \text { minutes, does } \\
\text { NOT include } \\
\text { laboratory data. }\end{array}$ & $\alpha=0.87$ & Not tested & $\begin{array}{l}\text { Small to moderate degree; } \\
0.66 \text { for worsening and } \\
-0.37 \text { for improvement }\end{array}$ \\
\hline $\begin{array}{l}\text { SLICC } \\
\text { Gladman } \\
1996^{49}\end{array}$ & $\begin{array}{l}42 \text { items in } 12 \\
\text { domains, } \\
\text { maximum score } \\
46\end{array}$ & $\begin{array}{l}0 \text { at diagnosis. } \\
>I=\text { damage }\end{array}$ & $\begin{array}{l}\text { I5 minutes some } \\
\text { items require } \\
\text { imaging and } \\
\text { ophthalmological } \\
\text { exam }\end{array}$ & & $\begin{array}{l}\text { Weak } \\
\text { relationship } \\
\text { with BILAG } \\
\text { (SRCC 0.25- } \\
0.28)\end{array}$ & $\begin{array}{l}\text { Higher scores early } \\
\text { correlated with mortality } \\
(1.56 \text { vs } 0.99)\end{array}$ \\
\hline
\end{tabular}

Abbreviations: BILAG, British Isles Lupus Assessment Group 2004 Index; SLEDAI, Systemic Lupus Erythematosus Disease Activity Index; SLAQ, Systemic Lupus Activity Questionnaire; SLICC, Systemic Lupus International Collaborating Clinics; SRCC, Spearman's Rank Correlation Coefficient; ICC, intraclass correlation coefficient.

Collaborating clinics/American college of Rheumatology Damage Index (SLICC-SDI) was created, $^{49}$ which assesses damage as the presence or absence of permanent or irreversible change in 12 systems present since the onset of the disease for at least 6 months.

The physician completes most of these composite indices. To incorporate the patient's perspective a questionnaire-based on PROs have been developed in 2003, the Systemic Lupus Activity Questionnaire (SLAQ) ${ }^{50}$ SLAQ is derived from the Systemic Lupus Activity Measure (SLAM), a physician-scored instrument, that assesses symptoms and objective findings present a month before the evaluation, but including items more amenable to being self-reported. SLAQ includes a patient severity global assessment (PGA) over the past month, a total of 24 specific symptoms, and a single Numerical Rating Scale (NRS) asking the patient to score disease activity level from 0 (no activity) to 10 (most activity) in the past three months.

Measure instruments in SLE are very complex, heterogeneous, and show low responsiveness, and this may explain, according to several lupus experts, the failure of some important clinical trials to show treatment efficacy in SLE. This aspect led to development of response indices, including the RIFLE, ${ }^{51} \mathrm{SRI}^{52}$ and the BICLA. ${ }^{53}$

Although a clinical judgement of disease activity based on physician experience is inevitable, it is desirable that validated disease activity indices are used even in routine clinical practice at least as a confirmation/guide for therapeutic decisions. To date, no data suggest the choice of one index over the others, however BILAG and SLEDAI are the most commonly used. In the European League Against Rheumatism recommendations for monitoring disease activity in SLE patients in routine clinical practice and in observational studies, the use of validated indices is recommended. ${ }^{54}$ 
However, as validated indices are still rarely used in clinical practice and are considered time consuming and too complex, it has been suggested PROMs may provide important information to complement the evaluation of disease activity.

Survival and long-term outcomes have improved considerably over the past decades in patients with SLE, leading to the recommendation of a treat-to-target strategy for these patients. ${ }^{55}$ There is no universally accepted definition of remission in SLE. However, it is important to identify an appropriate target for each patient in order to initiate treatment steps to try to achieve the defined target.

\section{Conclusions}

Inflammatory rheumatic diseases are very heterogeneous with a wide variety of clinical pictures that create challenges in assessing overall disease activity. A single measure may assess a very important aspect of the disease but does not reflect the global burden and the psychological impact on the patient's quality of life. Pooled indices are particularly useful as they integrate multiple aspects of disease activity into one single value. In addition, they improve the consistency of patient assessment and care across different clinical settings, and help patients and doctors better understand the disease and its impact on patient status. Incorporating measures in the clinical evaluation help to guide a treat-to-target strategy, which was initially developed for patients with RA and nowadays is also applicable to patients with SpA and SLE.

PROMs incorporate the patient's perspective and are feasible and informative to clinicians. All quantitative measures in routine care, such as laboratory data and PROMs should be considered as complementary information always in the context of the whole patient in clinical decisions. Overall, there is no doubt that composite indices of disease activity are of significant benefit not only in clinical trials but also in routine care, as they allow quantification and comparisons between a patient's disease activity levels over time and between larger populations. Thus, and based on the data presented in this narrative review, we strongly recommend the regular use of composite indices in the follow-up of patients with inflammatory rheumatic diseases.

\section{Disclosure}

JM and LT report no conflicts of interest for this work. IC has received honoraria and consulting fees from BristolMyers Squibb, Eli Lilly, Gilead, Abbvie, Novartis, and Galapagos, and reports expert advice and speaking engagements non related with this work for BristolMyers Squibb, Eli Lilly, and Galapagos, educational speaking engagements non related with this work for Novartis, speaking engagements non related with this work for Gilead, expert advice non related with this work for Abbvie, outside the submitted work, and reports no other potential conflicts of interest for this work.

\section{References}

1. Castrejon I, McCollum L, Tanriover MD, Pincus T. Importance of patient history and physical examination in rheumatoid arthritis compared to other chronic diseases: results of a physician survey. Arthritis Care Res (Hoboken). 2012;64(8):1250-1255. doi:10.1002/ acr.21650

2. Castrejon I, Gossec L, Carmona L. The EULAR Outcome Measures Library: an evolutional database of validated patient-reported instruments. Ann Rheum Dis. 2015;74(2):475-476. doi:10.1136/ annrheumdis-2014-206485

3. Rose HM, Ragan C, et al. Differential agglutination of normal and sensitized sheep erythrocytes by sera of patients with rheumatoid arthritis. Proc Soc Exp Biol Med Soc Exp Biol Med. 1948;68(1):1-6.

4. Nishimura K, Sugiyama D, Kogata Y, et al. Meta-analysis: diagnostic accuracy of anti-cyclic citrullinated peptide antibody and rheumatoid factor for rheumatoid arthritis. Meta-Analysis Research Support, Non-U.S. Gov't Review. Ann Intern Med. 2007;146(11):797-808.

5. Aletaha D, Neogi T, Silman AJ, et al. 2010 rheumatoid arthritis classification criteria: an American College of Rheumatology/ European League Against Rheumatism collaborative initiative. Ann Rheum Dis. 2010;69(9):1580-1588.

6. Pincus T, Castrejon I. Are patient self-report questionnaires as "scientific" as biomarkers in "treat-to-target" and prognosis in rheumatoid arthritis? Curr Pharm Des. 2015;21(2):241-256.

7. Verhoeven AC, Boers M, van Der Linden S. Responsiveness of the core set, response criteria, and utilities in early rheumatoid arthritis. Ann Rheum Dis. 2000;59(12):966-974. doi:10.1136/ard.59.12.966

8. Smolen JS, Landewe R, Bijlsma J, et al. EULAR recommendations for the management of rheumatoid arthritis with synthetic and biological disease-modifying antirheumatic drugs: 2016 update. Ann Rheum Dis. 2017;76(6):960-977. doi:10.1136/annrheumdis-2016210715

9. Singh JA, Saag KG, Bridges SL Jr, et al. 2015 American College of Rheumatology Guideline for the Treatment of Rheumatoid Arthritis. Arthritis Care Res (Hoboken). 2016;68(1):1-25. doi:10.1002/ acr.22783

10. van der Heijde DM, van 'T Hof M, Van riel PL, Van de putte LB. Development of a disease activity score based on judgment in clinical practice by rheumatologists. J Rheumatol. 1993;20(3):579-581.

11. Prevoo ML, van 't Hof MA, Kuper HH, van Leeuwen MA, van de Putte LB, van Riel PL. Modified disease activity scores that include twenty-eight-joint counts. Development and validation in a prospective longitudinal study of patients with rheumatoid arthritis. Arthritis Rheum. 1995;38(1):44-48.

12. Castrejon I, Ortiz AM, Garcia-Vicuna R, et al. Are the C-reactive protein values and erythrocyte sedimentation rate equivalent when estimating the 28-joint disease activity score in rheumatoid arthritis? Comparative Study Research Support, Non-U.S. Gov't. Clin Exp Rheumatol. 2008;26(5):769-775.

13. Castrejon I, Ortiz AM, Toledano E, et al. Estimated cutoff points for the 28-joint disease activity score based on C-reactive protein in a longitudinal register of early arthritis. Research Support, NonU.S. Gov't. J Rheumatol. 2010;37(7):1439-1443. doi:10.3899/ jrheum.091333 
14. Smolen JS, Breedveld FC, Schiff MH, et al. A simplified disease activity index for rheumatoid arthritis for use in clinical practice. Rheumatology (Oxford). 2003;42(2):244-257.

15. Aletaha D, Smolen J. The Simplified Disease Activity Index (SDAI) and the Clinical Disease Activity Index (CDAI): a review of their usefulness and validity in rheumatoid arthritis. Clin Exp Rheumatol. 2005;23(5 Suppl 39):S100-8.

16. Aletaha D, Nell VP, Stamm T, et al. Acute phase reactants add little to composite disease activity indices for rheumatoid arthritis: validation of a clinical activity score. Arthritis Res Ther. 2005;7(4):R796-806.

17. Pincus T, Yazici Y, Bergman MJ. RAPID3, an index to assess and monitor patients with rheumatoid arthritis, without formal joint counts: similar results to DAS28 and CDAI in clinical trials and clinical care. Rheum Dis Clin North Am. 2009;35(4):773-8, viii.

18. Castrejon I, Bergman MJ, Pincus T. MDHAQ/RAPID3 to recognize improvement over 2 months in usual care of patients with osteoarthritis, systemic lupus erythematosus, spondyloarthropathy, and gout, as well as rheumatoid arthritis. Research Support, Non-U.S. Gov't. $J \quad$ clin rheumatol. 2013;19(4):169-174. doi:10.1097/ RHU.0b013e3182936b98

19. Castrejon I, Pincus T. Patient self-report outcomes to guide a treat-totarget strategy in clinical trials and usual clinical care of rheumatoid arthritis. Clin Exp Rheumatol. 2012;30(Suppl. 73):S50-S55.

20. Ward MM, Castrejon I, Bergman MJ, Alba MI, Guthrie LC, Pincus T. Minimal clinically important improvement of routine assessment of patient index data 3 in rheumatoid arthritis. J Rheumatol. 2019;46 (1):27-30. doi:10.3899/jrheum.180153

21. Felson DT, Smolen JS, Wells G, et al. American College of Rheumatology/European League against Rheumatism provisional definition of remission in rheumatoid arthritis for clinical trials. Ann Rheum Dis. 2011;70(3):404-413. doi:10.1136/ard.2011.149765

22. Castrejon I, Dougados M, Combe B, Guillemin F, Fautrel B, Pincus T. Can remission in rheumatoid arthritis be assessed without laboratory tests or a formal joint count? possible remission criteria based on a self-report RAPID3 score and careful joint examination in the ESPOIR cohort. Research Support, Non-U.S. Gov't. J Rheumatol. 2013;40(4):386-393. doi:10.3899/jrheum.121059

23. Castrejon I, Dougados M, Combe B, Fautrel B, Guillemin F, Pincus T. Prediction of Remission in a French Early Arthritis Cohort by RAPID3 and other core data set measures, but not by the absence of rheumatoid factor, anticitrullinated protein antibodies, or radiographic erosions. $J$ Rheumatol. 2016;43(7):1285-1291. doi:10.3899/jrheum. 141586

24. Machado PM, Raychaudhuri SP. Disease activity measurements and monitoring in psoriatic arthritis and axial spondyloarthritis. Best Pract Res Clin Rheumatol. 2014;28(5):711-728. doi:10.1016/j. berh.2014.10.004

25. Sieper J, Rudwaleit M, Baraliakos X, et al. The Assessment of SpondyloArthritis international Society (ASAS) handbook: a guide to assess spondyloarthritis. Ann Rheum Dis. 2009;68(Suppl 2):ii1-44. doi:10.1136/ard.2008.104018

26. Garrett S, Jenkinson T, Kennedy LG, Whitelock H, Gaisford P, Calin A. A new approach to defining disease status in ankylosing spondylitis: the Bath Ankylosing Spondylitis Disease Activity Index. Comparative Study Research Support, Non-U.S. Gov't. J Rheumatol. 1994;21(12):2286-2291.

27. Braun J, Pham T, Sieper J, et al. International ASAS consensus statement for the use of anti-tumour necrosis factor agents in patients with ankylosing spondylitis. Ann Rheum Dis. 2003;62(9):817-824.

28. van der Heijde D, Sieper J, Maksymowych WP, et al. 2010 Update of the international ASAS recommendations for the use of anti-TNF agents in patients with axial spondyloarthritis. Ann Rheum Dis. 2011;70(6):905-908. doi:10.1136/ard.2011.151563
29. Cohen JD, Cunin P, Farrenq V, et al. Estimation of the Bath Ankylosing Spondylitis Disease Activity Index cutoff for perceived symptom relief in patients with spondyloarthropathies. $J$ Rheumatol. 2006;33(1):79-81.

30. Godfrin-Valnet M, Prati C, Puyraveau M, Toussirot E, LethoGyselink H, Wendling D. Evaluation of spondylarthritis activity by patients and physicians: ASDAS, BASDAI, PASS, and flares in 200 patients. Joint Bone Spine. 2013;80(4):393-398. doi:10.1016/j. jbspin.2013.01.003

31. Song IH, Rudwaleit M, Listing J, Sieper J. Comparison of the Bath Ankylosing Spondylitis Disease Activity Index and a modified version of the index in assessing disease activity in patients with ankylosing spondylitis without peripheral manifestations. Ann Rheum Dis. 2009;68(11):1701-1707. doi:10.1136/ard.2008.099226

32. Spoorenberg A, van Tubergen A, Landewe R, et al. Measuring disease activity in ankylosing spondylitis: patient and physician have different perspectives. Rheumatology (Oxford). 2005;44 (6):789-795. doi:10.1093/rheumatology/keh595

33. Lukas C, Landewe R, Sieper J, et al. Development of an ASAS-endorsed disease activity score (ASDAS) in patients with ankylosing spondylitis. Validation Studies. Ann Rheum Dis. 2009;68 (1):18-24. doi:10.1136/ard.2008.094870

34. Machado P, van der Heijde D. How to measure disease activity in axial spondyloarthritis? Research Support, Non-U.S. Gov't Review. Curr Opin Rheumatol. 2011;23(4):339-345. doi:10.1097/ BOR.0b013e3283470f 23

35. Fernandez-Espartero C, de Miguel E, Loza E, et al. Validity of the ankylosing spondylitis disease activity score (ASDAS) in patients with early spondyloarthritis from the Esperanza programme. Ann Rheum Dis. 2014;73(7):1350-1355. doi:10.1136/annrheumdis-2012-202976

36. Anderson JJ, Baron G, van der Heijde D, Felson DT, Dougados M. Ankylosing spondylitis assessment group preliminary definition of short-term improvement in ankylosing spondylitis. Arthritis Rheum. 2001;44(8):1876-1886. doi:10.1002/1529-0131(200108)44:8<1876:: AID-ART326>3.0.CO;2-F

37. Sieper J. How to define remission in ankylosing spondylitis? Ann Rheum Dis. 2012;71 Suppl 2:193-5. doi:10.1136/annrheumdis-2011200798

38. Schoels M, Aletaha D, Funovits J, Kavanaugh A, Baker D, Smolen JS. Application of the DAREA/DAPSA score for assessment of disease activity in psoriatic arthritis. Ann Rheum Dis. 2010;69 (8):1441-1447. doi:10.1136/ard.2009.122259

39. Mumtaz A, Gallagher P, Kirby B, et al. Development of a preliminary composite disease activity index in psoriatic arthritis. Ann Rheum Dis. 2011;70(2):272-277. doi:10.1136/ard.2010.129379

40. FitzGerald O, Helliwell P, Mease P, et al. Application of composite disease activity scores in psoriatic arthritis to the PRESTA data set. Ann Rheum Dis. 2012;71(3):358-362. doi:10.1136/annrheumdis-2011200093

41. Coates LC. Treating to target in psoriatic arthritis. Curr Opin Rheumatol. 2015;27(2):107-110. doi:10.1097/BOR.000000000 0000140

42. Coates LC, Fransen J, Helliwell PS. Defining minimal disease activity in psoriatic arthritis: a proposed objective target for treatment. Ann Rheum Dis. 2010;69(1):48-53. doi:10.1136/ard.2008.102053

43. Castrejon I, Pincus T, Wendling D, Dougados M. Responsiveness of a simple RAPID-3-like index compared to disease-specific BASDAI and ASDAS indices in patients with axial spondyloarthritis. RMD Open. 2016;2(2):e000235. doi:10.1136/rmdopen-2015-000235

44. Coates LC, Tillett W, Shaddick G, Pincus T, Kavanaugh A, Helliwell PS. Value of the routine assessment of patient index data 3 in patients with psoriatic arthritis: results from a tight-control clinical trial and an observational cohort. arthritis care res (hoboken). 2018;70(8):1198-1205. doi:10.1002/acr.23460 
45. Castrejon I, Tani C, Jolly M, Huang A, Mosca M. Indices to assess patients with systemic lupus erythematosus in clinical trials, long-term observational studies, and clinical care. Clin Exp Rheumatol. 2014;32 Suppl 85(5):85-95.

46. Arora S, Isenberg DA, Castrejon I. Measures of adult systemic lupus erythematosus: disease activity and damage. Arthritis Care Res (Hoboken). 2020;72(Suppl 10):27-46. doi:10.1002/acr.24221

47. Isenberg DA, Rahman A, Allen E, et al. BILAG 2004. Development and initial validation of an updated version of the British Isles Lupus Assessment Group's disease activity index for patients with systemic lupus erythematosus. Rheumatology (Oxford). 2005;44(7):902-906. doi:10.1093/rheumatology/keh624

48. Gladman DD, Ibanez D, Urowitz MB. Systemic lupus erythematosus disease activity index 2000. J Rheumatol. 2002;29(2):288-291.

49. Gladman D, Ginzler E, Goldsmith C, et al. The development and initial validation of the Systemic Lupus International Collaborating Clinics/American College of Rheumatology damage index for systemic lupus erythematosus. Arthritis Rheum. 1996;39(3):363-369.

50. Karlson EW, Daltroy LH, Rivest C, et al. Validation of a Systemic Lupus Activity Questionnaire (SLAQ) for population studies. Research Support, Non-U.S. Gov't Research Support, U.S. Gov't, P.H.S. Validation Studies. Lupus. 2003;12(4):280-286.

51. Petri M, Barr SG, Buyon J, Davis A, Ginzler E, Kalunian K. RIFLE: responder Index for Lupus Erythematosus [abstract]. Arthritis Rheum. 2000;43(Suppl 9):S244.

52. Furie RA, Petri MA, Wallace DJ, et al. Novel evidence-based systemic lupus erythematosus responder index. Arthritis Rheum. 2009;61(9):1143-1151. doi:10.1002/art.24698
53. Wallace DJ, Kalunian K, Petri MA, et al. Efficacy and safety of epratuzumab in patients with moderate/severe active systemic lupus erythematosus: results from EMBLEM, a phase IIb, randomised, double-blind, placebo-controlled, multicentre study. Ann Rheum Dis. 2014;73(1):183-190. doi:10.1136/annrheumdis-2012-202760

54. Mosca M, Tani C, Aringer M, et al. European League Against Rheumatism recommendations for monitoring patients with systemic lupus erythematosus in clinical practice and in observational studies. Consensus Development Conference Practice Guideline. Ann Rheum Dis. 2010;69(7):1269-1274. doi:10.1136/ard.2009.117200

55. van Vollenhoven RF, Mosca M, Bertsias G, et al. Treat-to-target in systemic lupus erythematosus: recommendations from an international task force. Ann Rheum Dis. 2014;73(6):958-967. doi:10.1136/annrheumdis-2013-205139

56. van Gestel AM, Anderson JJ, van Riel PL, et al. ACR and EULAR improvement criteria have comparable validity in rheumatoid arthritis trials. American College of Rheumatology European League of Associations for Rheumatology. J Rheumatol. 1999;26(3):705-711.

57. Pincus T, Swearingen CJ, Bergman M, Yazici Y. RAPID3 (Routine Assessment of Patient Index Data 3), a rheumatoid arthritis index without formal joint counts for routine care: proposed severity categories compared to disease activity score and clinical disease activity index categories. J Rheumatol. 2008;35(11):2136-2147.
Open Access Rheumatology: Research and Reviews

\section{Publish your work in this journal}

Open Access Rheumatology Research and Reviews is an international, peer-reviewed, open access journal publishing original research, reports, editorials, reviews and commentaries on all aspects of clinical and experimental rheumatology in the clinic and laboratory including the following topics: Pathology, pathophysiology of rheumatological diseases; Investigation, treatment and management

\section{Dovepress}

of rheumatological diseases; Clinical trials and novel pharmacological approaches for the treatment of rheumatological disorders. The manuscript management system is completely online and includes a very quick and fair peer-review system, which is all easy to use. Visit http://www.dovepress.com/testimonials.php to read real quotes from published authors. 